\title{
The Effectiveness of Wited Programme on Enrollment of Women in Technical and Vocational Education and Training (TVET)
}

\author{
Eunice Kanaga Najoli ${ }^{{ }^{*}}$ \\ ${ }^{1}$ Thohoyandou, SOUTH AFRICA
}

Received 2 March 2018 - Revised 19 November 2018 - Accepted 28 November 2018

\begin{abstract}
Women in Technical Education and Development (WITED) programme were identified by the Commonwealth Association of Polytechnics in Africa (CAPA) as an important factor for employability, innovation and sustainable development. The aim was to improve access of women to technical education. The effectiveness of WITED programme on the enrolment of women in Technical and Vocational Education and Training (TVET) was analysed. The study used simple random to sample 20 trainers and 100 trainees from three (3) TVET institutions in Western region of Kenya. At the same time, 3 Principals, 12 heads of departments (HODs), five (5) deans of students (DOS) and 10 technicians were sampled by purposive sampling. Data was collected by use of both questionnaire and structured interview schedule. Special Packages for Social Sciences (SPSS) version 20 was used to analyze results. Both descriptive and inferential statistics were presented in form of tables. Pearson correlation of -0.023 indicates that WITED program in TVET institutions is weak. This shows there is gender disparity in terms of enrolment, access, retention and completion rates in TVET. The main obstacles to women enrolment and exemplary performance in STEM courses include; cultural stereotypes and lack of role models as well as other socio-cultural factors.
\end{abstract}

Keywords: completion rates, employability, enrolment, WITED, program

\section{INTRODUCTION}

In today's world, technical education is taken as a tool to create job vacancies that can improve the livelihood of the people. This is in all sectors of the economy. Traditionally, it has been regarded as a preserve for the male gender. This perception has led to major omissions during the national government educational planning process. For instance, $30 \%$ of the total enrolment in TVET institutions comprise of female. However, only $5 \%$ of these female trainees enrol in Engineering, Mathematics and Building and Construction. UNESCO (2016) through UNEVOC understood the new role of TVET and set its aims towards attaining TVET for all, orienting Technical and Vocational Training and Strengthening TVET as part of lifelong learning (UNESCO, 1999). One of the main goals indicates the educational requirements for all people with emphasis on access to necessary education and programmes for those skills that are required in life.

The Commonwealth Association of Polytechnics in Africa (CAPA, 2013) has advocated for improving access to female in Technical Education, through establishment of female in Technical Education and Development WITED programmes as well as management and leadership training courses for managers in TVET institutions (CAPA, 2013). The main objectives of this programme include: increase of female enrolment in all training programmes in TVET institutions, promote equity in education, empower the female gender with skills, both formal and nonformal for the sake of improving the economy. Finally, make the livelihood better for the female gender. This paper highlights on the effectiveness of WITED programme in TVET institutions in Kakamega County, Kenya.

(C) 2019 by the authors; licensee Modestum Ltd., UK. This article is an open access article distributed under the terms and conditions of the Creative Commons Attribution License (http://creativecommons.org/licenses/by/4.0/). \ekanaga@mmust.ac.ke (*Correspondence) 


\section{Contribution of this paper to the literature}

- This study explores variables such as WITED programme and its effectiveness on enrolment trends, training, completion rates and employability in STEM courses.

- This study explores the influence of demographic variables such as female gender in strengthening and enhancing the study of STEM courses for professional development.

- Literature indicates that there is priority is to cultivate of workforce in STEM areas (National Science Board, 2007). It has therefore become importation in this century to have interdisciplinary learning frameworks. In the same spirit, educational programmes have to be connected to the STEM education. This provides an opportunity to train individuals who focus on development of appropriate current skills.

- The TVET institutions have been geared towards a transformative training that seeks alternatives to labour market, production of goods and services and employability. Creating specialized programmes does this and centres that are based on the unique production projects that facilitate the acquisition of skills, attitudes and knowledge for attaining quality training for sustainable development.

- The Commonwealth Association of Polytechnics in Africa (CAPA) has advocated for improving access to female in Technical Education, through establishment of female in Technical Education and Development WITED programme as well as management and leadership training courses for managers in TVET institutions, (CAPA, 2013).

- The main objectives of WITED programme include: increase of female enrolment in all training programmes in TVET institutions, promote equity in education, empower the female gender with skills that are necessary for economic development which would consequently improve the quality of their livelihood.

- In this respect, this study is important as it highlights on the effectiveness of WITED programme in enhancing enrolment in STEM courses.

\section{CONTRIBUTION TO THE BODY OF KNOWLEDGE}

Courses in STEM are an indication of knowledge and skills development for becoming future leaders. However, Sessional Paper Number14 (2015) on education asserts that there has been continued low enrolment of female in engineering, applied science, mathematics and technology departments.

Focused on sustainable development goals, Vision 2030 document identifies education and training as pivotal in leading the people in creativity, partnerships, employability and skills that enhance use of available technologies, research and sustainable development.

This Kenya's Vision 2030 suggests that there is need for intensified application of Science, Technology and Innovation (STI) with an aim of improving productivity and efficiency (GOK, 2007). This can be achieved through the effort of the Government of Kenya to provide adequate funds that can be used to conduct research to enhance capability of the human resource while at the same time improving the teaching effectiveness for STEM in schools, polytechnics and universities. Furthermore, there is need to establish new TVET institutions as well as enhance the collaboration between the institutions and the industry.

According to GOK (2008), there has been a review of the legal framework so as to establish a TVET Authority with the mandate regulate the systems. This is also meant to enhance the mechanisms of implementing the necessary TVET reforms with the aim of improving the capacity of this great educational sub-sector. However, there is scepticism among stakeholders that the establishment of TVET Authority may create duplication of roles within the Education ministry. Others feel that this may increase the red tape in management of issues in TVET, which may lead to more delays in programme implementation.

In addition, there is a gender policy in Education that is meant to help address issues such as enrolment, retention, retention, transition and achievement of both genders. TVET institutions have been geared towards a transformative training that seeks alternatives to labour market, production of goods and services and employability. Creating specialized programmes does this and centres that are based on the unique production projects that facilitate the acquisition of skills, attitudes and knowledge for attaining quality training for sustainable development.

Miller et al. (2006) indicates that generally, the female gender is underrepresented in STEM. Despite the fact that countries have tried to close gaps that are gender related in enrolment, it is not true for STEM based studies. A number of reasons have been given in an effort show why there is underrepresentation in STEM (Blickenstaff, 2005:369). The reasons include the following:

i. The biological difference between men and women,

ii. The difference in attitudes between men and women towards STEM, 
iii. Lack or inadequate role models in STEM professions who are women,

iv. Difference in childhood socialization and social pressures between men and women,

v. Difference in conditions of learning in the classroom,

vi. The whole organisation curriculum for STEM and the teaching methodology used.

According to Hyde (1996), several psychological studies established that there is a difference in the intelligence of men and women. However, these studies indicated that the difference that exist between the male and female genders in terms of intelligence relating STEM were insignificant, this has been suggested as one of the contributing factors to making girls not interested in STEM subject areas and professions.

In addition, traditional culture makes parents develop attitudes that consequently make them favour boys in terms of investment with the hope that they would not lose out but instead benefit from it in old age as social security. This makes some parents selectively send their children to school especially when the economic conditions are not favourable. In situations of inadequate resources and parents are faced with an option of taking children to school, they are likely to take boys instead of girls (Dorsey, 1999; 29). This is because they believe that when daughters get married, their income is used to enrich the families where they are married. One strategy of dealing with such situations is to substantially subsidize the education especially in communities with higher poverty levels.

Furthermore, lack of women professionals who are role models in STEM related professions that girls can look up to is another undoing (Dorsey 1999; 30). This makes the girls feel like these professions are for men and not for them. When it comes to the structure of STEM curricula, representation of STEM environments including the text and pictures all show men as the strong gender and women as spectators. Cultural expectations make matters worse by representing the woman as a weaker individual who should just be at home looking after her family.

According to Cerini et al. (2004), early years of education are important when it comes to how the teacher impacts on the learner's perception of science and related career. During progress in various levels of education, girls are faced by more challenges than boys. This makes girls drop out of the education system at a higher rate compared to the boys. Community's socio-cultural factors ranging from beliefs to attitudes about girls and boys are the variables that determine the gender gap in enrolment.

On the other hand, $\mathrm{Xu}$ et al. (2011) indicated learners' interests in STEM related studies are enhanced by teachers. This can be done by guidance, and scaffolding. At the same time, Sjaastad (2012) indicated that there are two kinds of people who influence that students STEM choices including those acting as models and those acting as definers. The models may be professionals in STEM including teachers, parents and close people displaying a STEM professional entity while definers may be parents or other people helping the young persons to set goals, define ethos that identify stronger educational aspects of choosing. Learners are expected to be shown by teachers on how STEM can be interesting by making learners interact with positive learning activities. However, this is not the case as some teachers are not well knowledgeable on finer details about the professions both within or outside STEM thus lacking confidence to offer career guidance to the learners (Stagg, 2007).

Wang (2013) indicates that there are so many factors that influence learners to enrol in STEM studies including individual, psychological, contextual and social factors making the enrolment complicated. For instance, Ministry of Health (1999) reports indicate that pregnancies may ruin a girl's educational ambitions if support from the school, family and community is not available to the adolescent mother. Mwamwenda (1995) argues that unwanted pregnancies in many African countries have led to the termination of girls' education, resulting in the loss of a bright future for the female girls. Becoming a teen mother is a huge challenge that affects all aspects of the girl's life: her personal, family, social and school life. The issue here is that without support, the teen mothers will be unable to fully come to terms with their motherhood and continue their education, which is crucial to their future financial and social independency (Rumberger, 1987).

Men have always dominated women when it comes to STEM. Due to this, Cobertt et al. (2010) have put the blame to factors that are environmental and social in nature. At the same time, Hyde $(2008 ; 494)$ indicates that the domination by men at highest levels of STEM "is caused by stereotype peddled by parents and teachers that girls and women lack mathematical ability."

Studies by Monique et al. (2001) agree with the above studies. They indicate that there are gender parities in favour of the male gender in ICT in both teaching and learning at both primary and secondary levels of education. On the other hand, Monique et al. (2005) complain about low numbers of women in fields that are related to technology. The scholars agree that the male gender if favoured when it comes to technology learning and activities in terms of access, participation and performance. This has led to a major worry among stakeholders worldwide.

Britner (2008) suggests that complexity of factors influencing enrolment has made many nations come up with policies that guide the enrolment of both gender to the various STEM courses. These policies address factors that affect attitude, interest, choice and participation. Based on the above suggestions there is need to answer the 
question: how effective is the WITED Programme on increase of women enrolment and to enhance training and employability in STEM courses.

\section{Sociological Theory}

This study adopted the feminist theory known as the Liberal Feminism. This theory advocates more for the inclusion of women in all social life aspects. The Liberal feminist theory argues that women like other human beings have a natural right to the same opportunities and freedoms. These rights are the same as what men have. Therefore, the general principle of liberty and equality should apply to both men and women. This should happen with the main aim of eradicating gender imbalances that exist while at the same time promote gender parity in the social lives of people. The theory indicates that the similarities between men and women is in terms of personality and any differences that may exist between the sexes are attributed to the social construction of gender and in fact, tend to enhance one set of androgynous virtues for both gender.

The theory informs the study that education opportunities therefore are supposed to open to both genders as well as encourage girls to go into technical, scientific and professional fields that used to be the domain of males. It informs the study on the contribution of women to the science related careers since 1830s. They managed to do all this in spite of them being ignored, prevented and/or subjugated within many communities that dealt with science. This mostly happened before the emergence of the women's rights movement in the 1960s and 1970s. The liberal feminists lay blame to the society. The say that the society is unfair to women in terms of limiting their both accessing to and being retained in certain fields of knowledge.

\section{METHODOLOGY}

\section{Research Design}

This study used descriptive survey research design to investigation the effectiveness of WITED Programme on women enrolment, training and employability in TVET institutions in Kakamega County, Kenya. Descriptive survey determines the status of a defined population with respect to one or more variables (Mugenda \& Mugenda, 2003). This design was appropriate since the study dealt with data from the population regarding gender enrolment in TVET institutions from 2010 to 2017. The researcher used the design to collect data on the participant's perception regarding how WITED programme has embraced enrolment, training and employability in TVET institutions in Kakamega County.

\section{Sampling Procedure}

The study employed the purposive sampling method in order to achieve depth in exploring and understanding (Berg, 2001; McMillan \& Schumacher, 2006) on the rate of gender enrolment in three (3) technical institutions. To achieve this, the study sites and the participants for the qualitative research design were purposively selected on the basis of their relevance and richness (Babbie, 2007; Cohen, Manion \& Morrison, 2007; McMillan \& Schumacher, 2006) in generating data that was of utility to the research and aspects of the study. Accordingly, 3 principals, 12 HODs, 10 technicians and five (5) Dean of students were purposively chosen as stakeholders and also people who are essential to the daily activities of institutions. For instance, the DOS work in collaboration with various departments and directly with students to ensure that student resources are up to date. The HODs and Deans of Students, being managers assist in the coordination of various administrative functions such as admission, financial aid, health services, social programmes and housing. This study selected 100 trainees from a population of 1,000 trainees in the 3 TVET institutions by the use simple random sampling. Wiersma (1995) denotes that sample sizes in qualitative research can typically be as small as $5 \%$. For a population of 1000 trainees, a sample of 100 was selected; this is $10 \%$ of the population. The study employed questionnaire and structured interview schedule to collect data from the trainees, technicians, deans of students and principals of the 3 institutions. While document analysis was used to collect Secondary information from intuitional records on gender enrolment. Data was analysed by use of Special Packages for Social Sciences (SPSS) version 20 and results of both descriptive and inferential statistics were presented in form of tables. Table 1 gives a summary of the sapling procedure and study sample size. 
Table 1. Summary of Sampling Procedure and Sample Size Matrix

\begin{tabular}{lcccc}
\hline Category of Respondents & Population (N) & Sample (n) & Percentage (\%) & Sampling Technique \\
\hline Trainees & 1000 & 100 & 10.00 & Simple Random Sampling \\
\hline Principals & 3 & 3 & 100.00 & Purposive Sampling \\
\hline Technicians & 50 & 10 & 20.00 & Purposive Sapling \\
\hline HODs & 18 & 12 & 66.7 & Purposive Sampling \\
\hline Deans of Students & 12 & 5 & 41.67 & Purposive Sampling \\
\hline Total & $\mathbf{1 0 8 3}$ & $\mathbf{1 3 0}$ & $\mathbf{1 0 0}$ & \\
\hline Source: Field data (2017) & & & &
\end{tabular}

Table 2. Enrolment percentages in technical institutions

\begin{tabular}{|c|c|c|c|c|c|c|c|c|c|c|c|c|c|c|c|c|}
\hline \multirow{3}{*}{ Dept. } & \multirow{2}{*}{\multicolumn{2}{|c|}{\begin{tabular}{|c|}
2010 \\
Percentage \\
\end{tabular}}} & \multirow{2}{*}{\multicolumn{2}{|c|}{\begin{tabular}{|c|}
2011 \\
Percentage
\end{tabular}}} & \multirow{2}{*}{\multicolumn{2}{|c|}{\begin{tabular}{|c|}
2012 \\
Percentage
\end{tabular}}} & \multirow{2}{*}{\multicolumn{2}{|c|}{\begin{tabular}{|c|}
2013 \\
Percentage
\end{tabular}}} & \multirow{2}{*}{\multicolumn{2}{|c|}{\begin{tabular}{|c|}
2014 \\
Percentage
\end{tabular}}} & \multirow{2}{*}{\multicolumn{2}{|c|}{$\begin{array}{c}2015 \\
\text { Percentage }\end{array}$}} & \multirow{2}{*}{\multicolumn{2}{|c|}{\begin{tabular}{c|}
2016 \\
Percentage
\end{tabular}}} & \multirow{2}{*}{\multicolumn{2}{|c|}{\begin{tabular}{c|}
2017 \\
Percentage
\end{tabular}}} \\
\hline & & & & & & & & & & & & & & & & \\
\hline & $\mathbf{M}$ & $\mathbf{F}$ & $M$ & $\mathbf{F}$ & $M$ & $\mathbf{F}$ & $\mathbf{M}$ & $\mathbf{F}$ & $M$ & $\mathbf{F}$ & $M$ & $\mathbf{F}$ & $\mathbf{M}$ & $\mathbf{F}$ & $M$ & $\mathbf{F}$ \\
\hline Science & 81 & 29 & 85 & 15 & 88 & 12 & 86 & 14 & 93 & 7 & 92 & 8 & 96 & 4 & 93 & 7 \\
\hline Technology & 72 & 20 & 88 & 12 & 87 & 13 & 84 & 16 & 88 & 12 & 92 & 8 & 95 & 5 & 94 & 6 \\
\hline Engineering & 90 & 10 & 94 & 6 & 94 & 6 & 96 & 4 & 96 & 4 & 96 & 4 & 97 & 3 & 96 & 4 \\
\hline Mathematics & 89 & 11 & 91 & 9 & 95 & 5 & 96 & 4 & 97 & 3 & 80 & 20 & 90 & 10 & 99 & 1 \\
\hline Average \% & 83 & 17 & 89 & 21 & 91 & 9 & 90.5 & 9.5 & 93.5 & 6.5 & 90 & 10 & 94.5 & 5.5 & 95.5 & 4.5 \\
\hline
\end{tabular}

Source: TVET Institutions' Registry Records (2017)

\section{Validity}

The instruments of the study were questionnaires and the interview schedule was validated through application of content validity determined by consultation with experts from STEM Departments in TIVET institutions. The second way in which the instruments were validated was through pre-testing and the responses from the respondents were used to improve the items.

\section{Reliability}

A pilot study was done in one TVET institution that was not included in the study. After a period of two weeks the researcher administered the instruments again to the same respondents. Responses from the respondents were checked for consistency and changes were made on the structure of questions. Data was analysed using SPSS computer programme. This was to test whether the instruments were reliable.

\section{RESULTS}

\section{Basic Descriptive Analysis of Variables}

To explore the effectiveness of Women in Technical Education and Development Programme (WITED) in the selected TVET institutions, enrolment, training, completion rates and training and employability were analyzed.

Table 2 analyses enrolment of both females and males from 2010 to 2017. This is mainly to show enrolment percentages of both female and males 3 years before and after the introduction of WITED programme in 2013. The table revealed that the male enrolment was on the increase before and after 2013 compared to the female gender. For instance, from 2010, 2011,2012, 2013 average male enrolment was 83\%, 89\%, 90\% and 90.5\% respectively. While average percentage of female enrolment remained low with $17 \%, 21 \%, 9 \%$ and $9.5 \%$ during the same period. Enrolment of males continued to increase after 2013 to an average percentage of above $90 \%$ while the female percentage staged low to an average percentage of 4.5 in 2017. This gender disparity continued to be more prevalent in in all the STEM courses up to 2017, three years after the introduction of the programme. The results in the table show gender disparities in enrolment.

It is clear that there is lower female enrolment in STEM programmes as compared to their male counterparts as from 2010 to 2017. The female participation in the science and mathematics courses decreased from 2011 to 2016. However, there is a steady progressive increase in enrolment of females in Technology and engineering from the year 2013 to 2017. The progress of the females is slowly compared to the males thus rendering gender parity unattainable. This clearly shows that the secondary school subjects that are required for female students to enrol in TVET courses are a major hindrance. It is also clear that fewer females enrolled in technical education and pursued it to completion compared to the males. This therefore implies that there remains low enrolment and completion rates of female gender in TVET even after the introduction of WITED programme. 
Table 3. Causes of low Enrolment of females in STEM courses

\begin{tabular}{lccccc}
\hline Department & $\begin{array}{c}\text { Heavy course content } \\
\text { for females }\end{array}$ & $\begin{array}{c}\text { Stereotype STEM is } \\
\text { for males }\end{array}$ & High entry grade & Few mentors & Total \\
\hline Science & $16.3 \%$ & $76.7 \%$ & $7.0 \%$ & $0.0 \%$ & $100.0 \%$ \\
\hline Engineering & $15.6 \%$ & $51.1 \%$ & $26.7 \%$ & $6.7 \%$ & $100.0 \%$ \\
\hline Technology & $9.1 \%$ & $40.9 \%$ & $31.8 \%$ & $18.2 \%$ & $100.0 \%$ \\
\hline Mathematics & $0.0 \%$ & $80.0 \%$ & $0.0 \%$ & $20.0 \%$ & $100.0 \%$ \\
\hline
\end{tabular}

Source: Field Data, (2017)

Table 4. Effectiveness of WITED Programme in Increasing Enrolment of Women in TVET Institutions

\begin{tabular}{|c|c|c|c|}
\hline \multirow{2}{*}{ Department } & \multicolumn{2}{|c|}{ WITED Programme in TVET institution } & \multirow{2}{*}{ Total } \\
\hline & 0-2 weak & 3-4 moderately weak & \\
\hline Science & $83.7 \%$ & $16.3 \%$ & $100.0 \%$ \\
\hline Engineering & $53.3 \%$ & $46.7 \%$ & $100.0 \%$ \\
\hline Technology & $81.8 \%$ & $18.2 \%$ & $100.0 \%$ \\
\hline Mathematics & $50.0 \%$ & $50.0 \%$ & $100.0 \%$ \\
\hline
\end{tabular}

Source: Field data (2017)

This low completion rates limits the number of female at professional and managerial job levels (Republic of Kenya, 2004).

Studies by (Akeyo, 2012) studies agree that serious gender disparities in enrolment exists between regions in favour of male with regards to access, retention completion, performance and transition. This study concurs with reports by Portfolio Committee on Higher Education and Training (2016) that students come late to register at TVET colleges, often after failing to secure spaces at universities. According Hill et al. (2010), men have always outnumbered women in STEM fields because of social and environmental factors. At the same time Hyde and Lindberg (2008:494) indicated that the women under-representation at higher levels of STEM fields is caused by parents and teachers who generally believe that, "Girls and women lack mathematical ability." Table 3 shows the causes of low enrolment of females in STEM courses in TVET.

Results in Table 3 indicate a number of factors that explain the causes of gender disparity when it comes to that participation of men and women in STEM fields. The Deans of students informed the study that the causes of gender differences in gender enrolment included: heavy entry grade for STEM courses for female students, Stereotype beliefs that STEM is for males, and few mentors in STEM courses among others (Table 3). Sixteen point three percent $(16.3 \%)$ dean respondents indicated that there is low female enrolment in science because the course content is heavy for females compared to males, seventy six percent $(76 \%)$ indicated social cultural stereotyping that science is meant for males and $7.0 \%$ of the deans indicated that the entry grade in science courses is high for women. In comparison, $15.6 \%, 40.9 \%$ and $9.1 \%$ of the respondents from engineering and technology indicated low female enrolment is caused by heavy course content respectively. Fifty-one point one $(51.1 \%), 40.9 \%$ and $80 \%$ from engineering. Technology and mathematics connected low enrolment of female students to social cultural stereotyping beliefs that the courses are for males. Salta et al. (2004) observed that when dealing with gender issues, cultural factors must be tackled since for a long period of time globally, cultural factors have been construed to be the main cause of gender inequality. These findings concur with Ceci et al. (2009) who revealed that socio-cultural factors play a major role in the limited human diversity found in STEM fields. Seven percent (7\%), 26.7\% and $31 \%$ deans of students indicated that STEM course content is heavy for females compared to the males in science, engineering and technology. Few mentors in STEM course were also mentioned by $6.7 \%, 18.2 \%$ and $20 \%$ of the respondents from science, engineering and technology departments respectively. A study by Kane (2004) concur that most of the STEM textbooks have boys as key figures for examples in depicting Science and Technology. Babco and Bell (2004); NSF (2013) agree that the variability in the demographic diversity across Science, Technology, Engineering and Mathematics fields is another reason for the role of cultural factors in the female gender participation. Girls and women remain under-represented due to the ancient perceptions of appropriate roles in developing countries. This has presented female gender to advance their career so that they commit their time to family matters. See Table 4 for the effectiveness of WITED Programme to increase enrolment of women in TVET institutions.

Table 4 has findings, which indicate that $83.7 \%$ of HOD respondents from science department rated the programme weak; $53.3 \%$ from the engineering department rated it weak while 46.7 rated it moderately weak. Eighty one point eight percent $(81.8 \%$ ) of the respondents from Technology department and $50 \%$ from mathematics department said that the WITED programme is generally weak in helping increase woman enrolment in STEM courses. While $16.3 \%$ of HODs respondents from science, $46.7 \%$ of engineering, $18.2 \%$ of Technology and $50 \%$ from Mathematics department said that it's moderately weak. None of the respondents said the programme is average, good or very good. According to Equate (2008), for any programme to effectively address gender inequality in 
Table 5. Female Completion Rates in TVET

\begin{tabular}{|c|c|c|c|c|c|c|c|c|c|c|c|c|c|c|c|}
\hline \multirow{3}{*}{ Dept } & \multicolumn{15}{|c|}{ Year } \\
\hline & \multicolumn{3}{|c|}{2012} & \multicolumn{3}{|c|}{2013} & \multicolumn{3}{|c|}{2014} & \multicolumn{2}{|c|}{2015} & \multicolumn{4}{|c|}{2016} \\
\hline & Enr & Com & $\%$ & Enr & Com & $\%$ & Enr & Com & $\%$ & Enr & Com & $\%$ & Enr & Com & $\%$ \\
\hline Sci & 32 & 18 & 44 & 30 & 10 & 33 & 22 & 10 & 45 & 17 & 07 & 41 & 20 & 08 & 40 \\
\hline Eng & 54 & 24 & 55 & 12 & 20 & 16 & 53 & 20 & 38 & 45 & 26 & 58 & 43 & 14 & 32 \\
\hline Tec & 31 & 15 & 47 & 28 & 12 & 42 & 20 & 10 & 50 & 46 & 10 & 21 & 43 & 09 & 20 \\
\hline Math & 31 & 16 & 52 & 26 & 10 & 38 & 12 & 06 & 50 & 10 & 05 & 50 & 14 & 06 & 64 \\
\hline Total & 117 & 73 & 49.5 & 96 & 52 & 32.6 & 236 & 46 & 45.8 & 118 & 48 & 42.5 & 120 & 37 & 39 \\
\hline
\end{tabular}

Source: Field data (2017)

Key:

Enr - Number of female students Enrollment

Com - Number of female students Completed

$\%$ - Percentage of Completion rate

Dept - Department of enrollment by student

education, it must tackle the issue both in the classroom and in the community in which it is implemented. Such a strategy may include coming up with activities that enhance learning activities in school that address gender discrimination in families and communities at large. For any meaningful long-term impact to be felt, the strategies must go beyond the school so that they can influence the gender issues in the homes and the society at large. Tietjen (1991) and Aikman (2005) observe that for long lasting change to occur, an education programme must endeavour to identify the gender concerns and address them at the highest level of decision-making where gender-equitable policies can be developed and implemented. If this is not the case, any gains made either in the classroom or in the community can easily be undermined by developed policies that do not enhance gender equity.

Table 5 shows enrolment and completion rates of the female gender from 2012 to 2016. In 2012, the total number of female students enrolled in STEM courses were 117, and 73 completed giving 62\% completion rate; 2013, 96 were enrolled and 52 completed giving 54\% completion rate; 2014, 236 enrolled and 46 completed with $19 \%$ completion rate; 2015, 118 students enrolled and 48 completed with $40.6 \%$ completion rate and in the year 2016, 120 female students enrolled and 37 completed with $30.9 \%$ completion rate. The table also shows a drop in enrolment of female students from 117 in 2012 to 96 in 2013. In 2014, 236 were enrolled compared to 118 in 2015 and 120 in 2016 respectively. The results show that there is low female completion rate. This negates WITED goals to improve enrolment of woman in courses offered by the TVET institutions. It also negates the efforts to promote equity in education and empower women and girls with formal and non-formal skills for economic development. These findings are in agreement with Monique and Eck (2001) who observed that fewer females enrolled in technological courses is a reason to worry for the world because they drop out before completion to meet commitments of the family. The studies suggest have suggested that there is need for kits to be used in training or have science packages offered by multimedia resources. These are meant to motivate them to be interested more in the science education.

On the other hand (Espinosa, 2011) studies observed that females who were persistent in STEM fields of study comfortably discussed course content with peers, were able to join field related student associations, participate in research projects for undergraduate, attend private colleges and could comfortably attend colleges with students who are serious about STEM courses. Interviewed HODs and Principals pointed out retention and completion rates as strategies to improve: female -learners to be given sponsorship; closely monitored and encouraged to re-do referrals and also have mentorship programmes. Deans of students suggested strategies for enhancement such as; motivational in inspirational talks; careers talks; scholarships; awareness campaigns; debates, conferences; congresses for woman-learners and heart to heart talks. The study investigated on employment of graduates from TVET. Figure 1 shows percentage distribution of STEM graduates in the job market. 


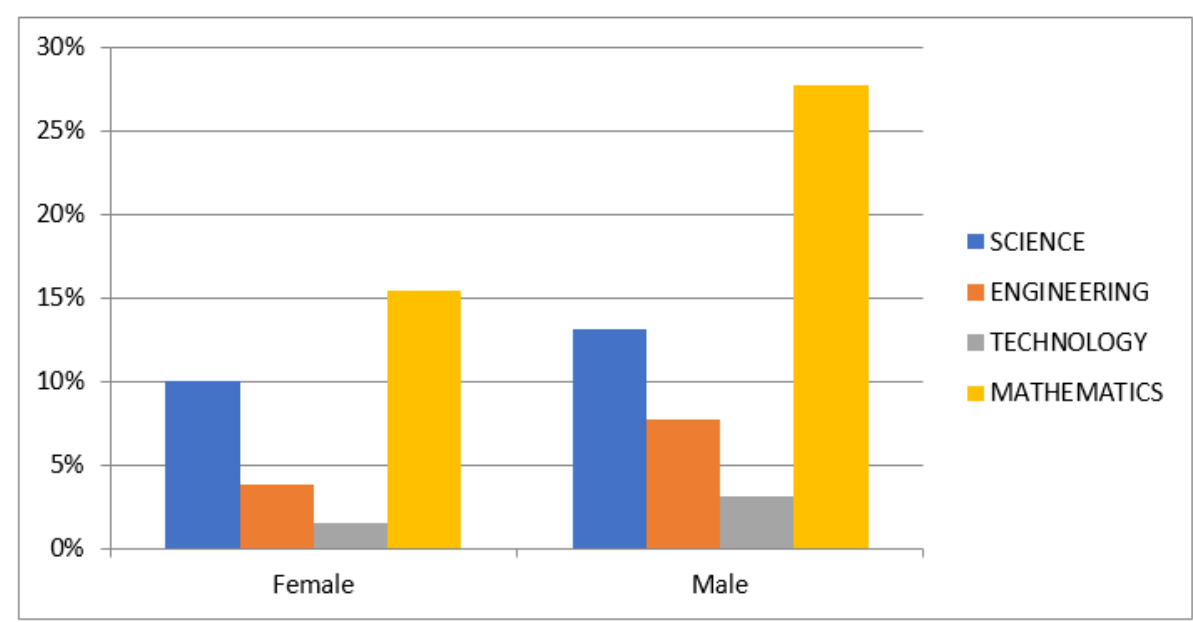

Figure 1. Employment percentage of gender in STEM Courses Source: TVET Institutions Return Records (2017)

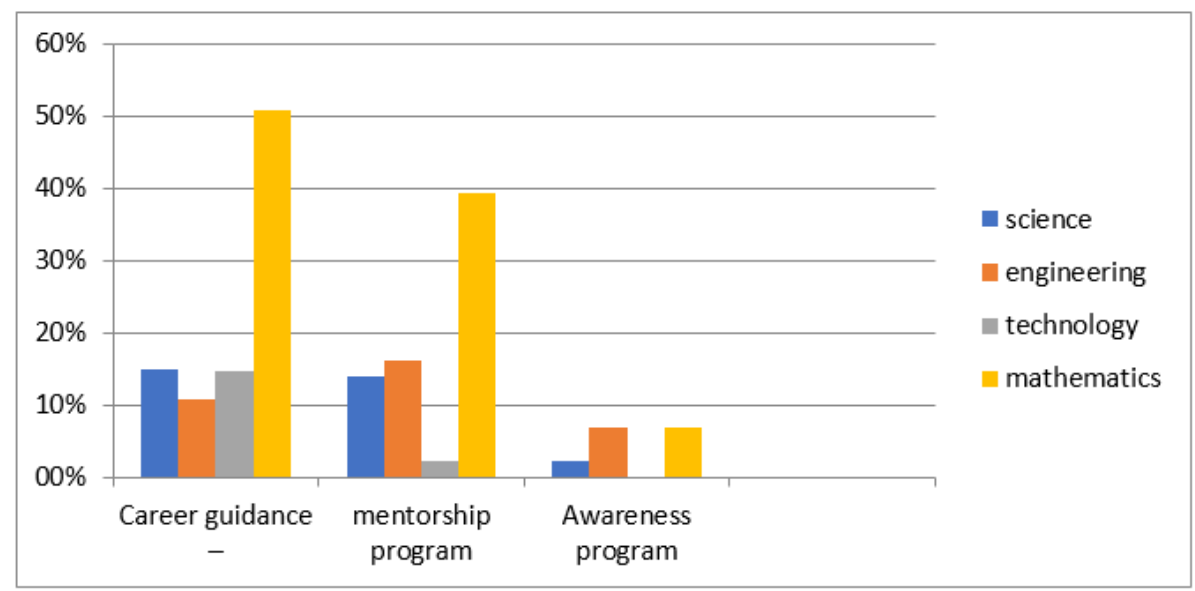

Figure 2. Strengthening and Enhancing STEM Courses. Source: Field data (2017)

The figure shows the percentage distribution of TVET graduates by employment status and gender. The figure shows that, $10 \%$ of the female who enrolled and completed Science courses got employment compared to $15 \%$ of male gender; $3 \%$ of the woman enrolled and completed engineering course got employment compared to $7 \%$ of the male gender; $1 \%$ of the woman enrolled and completed technology course got employment against 3\% male; and $15 \%$ of woman student s who graduate in mathematics got employed compared to $27 \%$ of the male gender. Whilst interviewed HODs attributed good performance and employability of males to self-discovery and hard work; trainee's devotion and good learners-teachers relationship, the females' poor performance was attributed to negative attitude; fear of STEM subjects; uncooperative parents; lack of course requirements; and absenteeism.

Studies done by (Siyanbola \& Taiwo, 2013) on the same observed that quality of TVET graduates in the open market has been on a decline trend in the resent years because of poor pedagogy, inadequate equipment for training, ineffective work experience and supervision while on industrial attachment. These studies suggested that all female-learners in TVET should be encouraged to understand the relevance of STEM courses because they are marketable; recognizable internationally and one could venture into salaried or self- employment. Mburu (2016) study agree with the above studies that when TVET graduates get to the job market, they get shocked because of lack of adequate skills required in the labour market due to the poor quality of the training programmes. Lack of participation of the industries in the development of the curriculum makes training institution offer training programmes that are not market driven as per the demands of the job market. In addition, Mburu (2016) suggests that there is need to marry the objectives and outputs of the training programmes and the social requirements and the needs of the industry. During interview, TVET principals informed the study on the same that students are always reminded about the importance of STEM courses as bedrock for innovation in business and industry. The study also investigated on how to strengthen and enhance women to study STEM courses. Figure 2 shows the results. 
Figure 2 indicates responses on how to strengthen and enhance female enrollment to complete STEM courses. Fifteen point four percent $(15.4 \%)$ of HOD respondents from science department indicated the need for career guidance programmes to be initiated in TVET institutions compared to $10.8 \%$ from engineering department, 14.65 from technology and $10 \%$ from mathematics. Fifteen point four percent $(015.4 \%)$ from science department, $16.2 \%$ from engineering department, $2.3 \%$ technology and 5.4\% from the mathematics department indicated the need for mentorship programmes to motivate female students to choose STEM courses. Awareness was reported by $6.9 \%$ of the respondents from the engineering and Mathematics departments. Deans of students revealed to the study that most of the female students do not know what the labour market requires, and lacked support and guidance in finding employment after completing their training. They suggested that female students should be given equal opportunities to take STEM courses without being forced by their tutors. There is also need for creating awareness of STEM courses in communities, schools and religious setups. The HODs suggested the need for collaboration amongst TVET Institutions, Industry and WITED Chapters to continue campaigning and spearheading females towards STEM courses; to give incentives in form of bursaries to female learners who excel in academic performance; offer mentorship programmes and allocate funding to female-learners by governments and organizations.

There is need to pressurize the government to enhance gender equality by enrolling more women in TVET training programmes that are dominated by the male students. The provision of bursaries by the government should enable more female students to register for the STEM courses and reduce dropout rates so as to achieve gender equality in such courses. This will enable train through TVET institutions, get into the labour market, increase family income, which is an important contributor to alleviation to poverty.

Table 6. Source: field data (2017)

\begin{tabular}{|c|c|c|c|}
\hline \multicolumn{4}{|c|}{ CORRELATIONS } \\
\hline & & $\begin{array}{c}\text { WITED PROGRAMME in TVET } \\
\text { institution }\end{array}$ & $\begin{array}{c}\text { Reasons for Low Girl } \\
\text { enrolment in STEM DEPTS }\end{array}$ \\
\hline \multirow{3}{*}{$\begin{array}{l}\text { WITED PROGRAMME in } \\
\text { TVET institution }\end{array}$} & Pearson Correlation & 1 & -.023 \\
\hline & Sig. (2-tailed) & & .799 \\
\hline & $\mathrm{N}$ & 130 & 130 \\
\hline \multirow{3}{*}{$\begin{array}{l}\text { Reasons for Low Girl } \\
\text { enrolment in STEM } \\
\text { DEPTS }\end{array}$} & Pearson Correlation & -.023 & 1 \\
\hline & Sig. (2-tailed) & .799 & \\
\hline & $\mathrm{N}$ & 130 & 130 \\
\hline
\end{tabular}

A correlation of 0.023 indicate that WITED program in TVET institutions is weak.

\section{CONCLUSIONS}

Achievement of parity is the main objective and is the basic principle to gender equality. One way of ensuring quality education for all is to strike a balance in the factors such as quality, access and relevance of the courses. To achieve access equitably means that both genders have equitable chances to be enrolled into formal, non-formal or other educational approaches. Results of this study showed that segregation of gender or differences in enrolment in STEM courses still existed. The differences in enrolment indicate that the selection of the subjects for the boys and girls continue to differ with more males showing preference to enrol in STEM courses compared to their female counterparts. As far as the rates in participation are concerned, it can be concluded that males have an attraction for STEM programmes. According to Dalgety and Coll (2004), students choosing which training programme to enrol in are influenced by teachers, parents, peers and relatives. Female students are influenced more when it comes to STEM courses. A good number of science students in tertiary institutions believe in the stereotypes associated with the STEM courses linked to the experiments, white coats and laboratory work. At the same time, Salta and Tzougraki (2004) established that female students generally express negative attitudes concerning the difficulty in the STEM courses. They perpetuate a social stereotype that male students were naturally scientists. This study revealed several factors that affect enrolment of female students in the TVET courses. They include interests and attitudes towards TVET training programmes; and the selection of subjects in secondary schools, TVET policies, culture course content of STEM related courses towards females; the entry grade for STEM related courses is high for the woman and finally there are few female mentors employed in STEM departments to facilitate motivation and mentoring roles. The studies also found out that female enrolled through the WITED programme in TVET institutions have low completion rates.

This therefore indicate that gender equality in TVET is not realized, and it generally lacks essential actions provided by various stakeholders which include training and specific sectors of employment. This implies that policy makers must ensure that laws promote gender equality in the workplace and incentivize employers to create female-friendly work environments. It is important to develop initiatives and protective policies guaranteeing the rights of girls and female in the workforce, and the need to collaborate with employers to ensure that workplaces are supportive of young woman employees. Therefore, this study makes a conclusion that there is need for an all- 
inclusive methodology involving all important stakeholders to formulate and implement relevant laws, policies and programmes so as to deal with needs of enrolment including short term, medium term and long term for this would a solution that is more effective.

\section{REFERENCES}

Aderemi, H. O., Hassan, O. M., Siyanbola, W. O., \& Taiwo, K. (2013). Trends in Enrollment, Graduation and Staffing of Science and Technology Education in Nigeria Tertiary Institutions: A Gender Participation Perspective. Educational Research and Reviews, 8(21), 2011-2020. http:/ / www.academicjournals.org/ERR

Aikman, S. E., \& Chloe, Cr. (2005). The Education MDGs: Achieving Gender Equality through Curriculum and Pedagogy Change. Gender and Development, 13(1), 44-55. https:/ / doi.org/10.1080/13552070512331332276

Akeyo, N., \& Achieng, N. R. (2012). Study on the Factors affecting Acquisition of Vocational Skills among Youth Learners in Maranda Division, Siaya County (Unpublished Masters Project), University of Nairobi.

APA. (2013). Reorienting TVET towards Sustainable Development, CAPA Secretariat, Nairobi, Kenya.

Ayonmike, C. S. (2014). Quality Technical, Vocational Education and Training: A Tool for Self Reliance. IOSR Journal of Computer Engineering (IOSR-JCE), 17(1), 30-35. Retrieved from www.iosrjournals.org

Blickenstaff, J. C. (2005). Women and science careers: Leaky pipeline or gender filter? Gender and Education, 17(4), 369-386. https://doi.org/10.1080/09540250500145072

Bonn Declaration (2014). Strengthening And Supporting TVET Colleges For Expanded Access And Increased Programme Quality, 15 August 2014.

Britner, S. L. (2008). Motivation in high school science students: A comparison of gender differences in life, physical, and earth science classes. Journal of Research in Science Teaching, 45(8), 955-970. https:/ / doi.org/10.1002/tea.20249

Cerini, B., Murray, I., \& Reiss, M. (2004). Student review of the science curriculum. London: Planet Science. http:/ / scholar.google.com/scholar_lookup?title=Student $\% 20$ review $\% 20$ of $\% 20$ the $\% 20$ science $\% 20$ curriculu m\&author=B.\%20Cerini\&author=I.\%20Murray\&author=M.\%20Reiss\&publication_year=2004

Committee of Higher Education and Training. (2016). Department of Higher Education and Training Community Education and Training College. Recommended Executive Committee Charter Annexure 4.

Dahl, J. (2003). How much are distance education faculty worth. Distance Education Report, 7(14), 5-7.

Dalgety, J., \& Coll, R. K. (2004). The influence of normative beliefs on students' enrolment choices. Research in Science E Technological Education, 22(1), 59-80. https:/ / doi.org/10.1080/0263514042000187548

Dorsey, B. J. (1999). Gender Inequalities in Education in the Southern Africa Region: An analysis of Intervention Strategies. Harare, UNESCO Publications

Ekine, A., \& Abay, N. (2013). A gender participation perspective, 8(21), 2011-2020. http:/ / www.academicjournals.org/ERR

Equate (2008a). Education from a gender equality perspective. Washington, DC: Management Systems International. Retrieved from http://www.usaid.gov/ourwork/cross-cutting_programmes/wid/pubs/Education

Espinosa, L. (2011). Pipelines and Pathways: Women of Color in Undergraduate STEM Majors and the College Experiences that Contribute to Persistence. Harvard Educational Review: June 2011, 81(2), $209-241$. https:/ / doi.org/10.17763/haer.81.2.92315ww157656k3u

GoK. (2007). Kenya Vision 2030. Nairobi: Government Press.

GoK. (2008). Economic Survey. Nairobi: Government Press.

Hill, C., Corbett, C., \& Rose, A. St. (2010). Why So Few? Women in Science, Technology, Engineering and Mathematics. NW, Washington DC: American Association of UniversityWomen.

Hyde, J. S., \& Linn, M. C. (2006). Gender similarities in mathematics and science. Science, 314(5799), 599-600. https://doi.org/10.1126/science.1132154

Key, J. D., Barbosa, G. A., \& Owens, V. J. (2001). The second chance club: Repeat adolescent pregnancy prevention with a school-based intervention. Journal of Adolescent Health, 28(3), 167-169. https:/ / doi.org/10.1016/S1054139X(00)00186-5

Mburu, E. N. (2016). Competency Based Training (CBT) Promotes Education and Training in TVET Institutions for the World. https://www.academia.edu/10178383/Competency_based_Training_CBT_Promotes_Education_ and_Training_in_TVET_institutions_for_the_world_of_Work_ 
Millar, R., \& Osborne, J. (2001). Beyond 2000: Science education for the future. London: King's College London. http:/ / scholar.google.com/scholar_lookup?title=Beyond $\% 202000 \% 3$ A $\% 20$ Science $\% 20$ education $\% 20$ for $\% 2$ 0the $\%$ 20future\&author $=$ R. \%20Millar\&author=J.\%20Osborne\&publication_year $=2001$

Ministry of Health. (1999). School Pregnancy in Kenya: A Report of a Study of Discontinuation Rates and Associated Factors. Nairobi: Ministry of Health - GTZ Support Unit.

MoEST. (2003). National Action Plan on Education for All 2003-2015. Nairobi: Government Press.

MoEST. (2005). Sessional Paper No.1 of 2005, Policy Framework for Education, Training and Research. Meeting the challenges of Education, Training and Research in Kenya in the 21st century. Nairobi: Government Press.

MoEST. (2015). Kenya Education Sector Support Programmeme. Nairobi: Government Press.

Mwamwenda, T. (1995). Educational Psychology : An African Perspective Edition statement NSF (2013). A skilled and capable workforce that shares in, and contributes to, the benefits and opportunities of economic expansion and an inclusive growth path. Progress Report 2011 - 2013.

Rumberger, R. W. (1987). High school dropouts: A review of issues and evidence. Review of Educational Research, 57(2), 101-121. https:/ / doi.org/10.3102/00346543057002101

Salta, K., \& Tzougraki, C. (2004). Attitudes toward chemistry among 11th grade students in high schools in Greece. Science Education, 88, 535-547. https:/ / doi.org/10.1002/sce.10134

Sjaastad, J. (2012). Sources of inspiration: The role of significant persons in young people's choice of science in higher education. International Journal of Science Education, 34(10), 1615-1636. https:/ / doi.org/10.1080/09500693.2011.590543

Stagg, P. (2007). Careers from science: An investigation for the Science Education Forum. Warwick: Centre for Education and Industry (CEI). http:/ / scholar.google.com/scholar_lookup?title=Careers $\% 20$ from $\% 20$ science $\% 3 \mathrm{~A} \% 20$ An \%20investigation \%20for\%20the\%20Science\%20Education \%20Forum\&author=P.\%20Stagg\&publication _year $=2007$

Tietjen, J. (1991). Gender equality in education: Definitions and measurements (Background paper for UNESCO GMR 2003-043). Paris, France: UNESCO. Retrieved from http:/ / portal.unesco.org/education/en/file_download. php/daa3a7d75587a9ae6c90e68d961a5229Gender+equality+in+Education

UNESCO. (1999). Second International Conference on Technical and Vocational Education: final report. Paris: UNESCO.

UNESCO. (2003). Global Education Digest. Paris. Retrieved from http:/ / www.uis.unesco.org/template/pdf/ged/2005/ged2005 en.pdf

UNESCO. (2010). International Centre for Technical and Vocational Education and Training. (UNESCO-UNEVOC). Entrepreneurship education as a tool to support self-employment in Kenya.

Volman, M., \& van Eck, E. (2001) Gender Equity and information in education. The second edition. Review of educational research, Journals Sage.

Volman, M., van Eck, E., Heemskerk, I., \& Kuiper, E. (2005). New technologies, new differences. Gender and ethnic differences in pupils' use of ICT in primary and secondary education. Computers $\mathcal{E}$ Education, 45(1), 35-55. https:/ / doi.org/10.1016/S0360-1315(04)00072-7

Wang, X. (2013). Why students choose STEM majors: Motivation, high school learning, and postsecondary context of support. American Educational Research Journal, 50(5), 1081-1121. https:/ / doi.org/10.3102/0002831213488622

Xu, J., \& Corno, L. (2011). Promoting Student Interest in Science: The Perspectives of Exemplary African American Teachers. American Educational Research Journal February 2012, 49(1), $124-154$. https://doi.org/10.3102/0002831211426200

\section{http://www.ejmste.com}

